\title{
DEVELOPMENT OF WOOD GRINDING 2. EFFECTS OF WOOD MOISTURE ON FIBRE PROPERTIES
}

\author{
BRUNO LÖNNBERG \\ Pulping Technology, Åbo Akademi University, Åbo, Finland \\ \orresponding author: Professor Emeritus B. Lönnberg, blonnber@abo.fi
}

Received December 15, 2020

The wood grinding model recently published was based on an energy balance of the active grinding zone, i.e. the limited volumes of wood and grindstone that were heated by the grindstone generated compression and tension strains in the wood surface. Generally speaking, the data obtained in well controlled laboratory grindings complied with the derived model meaning that compression-tension power ratios presented as a function of the specific pulp production resulted in linears. However, the wood moisture contents varying from water-saturated to air-dried wood needed further elaboration for better understanding.

Accordingly, the aim of this presentation was to find reasonable explanations for the grinding effects on the wood fibres by considering groundwood pulp and paper sheet properties, for example shives and fines contents, as well as tensile strength and light scattering of the paper sheet. The compression-tension power ratios provided by the model reflect simultaneously both compression and tension strain in wood, and accordingly, the resulting fibre properties would be dependent on both brittle and tough fractures. Evidently, the water contents played a role in this context, both as a stiffener of the water-saturated wood, and as a wood and fibre coolant.

Keywords: compression, fibre, fines, grinding, groundwood, light scattering, moisture, power, shives, spruce, tensile strength, temperature, tension, wood

\section{INTRODUCTION}

It is worth mentioning that the data referred to in this study were possible as Fagerhed ${ }^{1}$ planned and built a laboratory wood grinder for production of groundwood pulps under controlled conditions, and that the data applied here were extracted from Riissanen's work. ${ }^{2}$

In a recent publication ${ }^{3}$ presenting a novel grinding model - based on an energy balance comprising the grinding zone $e^{4,5}$ - the laboratory grinding data ${ }^{2}$ provided linears when tested as suggested by the model. The grinding mechanism appeared identical for waterimpregnated wood, naturally fresh wood and airdried wood presenting moisture contents of 65 , 58 and $15 \%$, respectively.

Considering the compression-tension power ratios, in accordance with the model, reasonable explanations would be obtained for the pulp and paper properties essential in paper making. The compression-tension power ratios applied in mechanical stone grinding of wood are supposed to cause fibrillation of the fibres, as long as they are part of the wood matrix. The relatively low compression power generated by low compression rates is supposed to produce viscoelastic strain, while again the high tension powers, including high stone speeds, would rather develop elastic strain in the wood surface.

\section{PULP SHIVES AND FINES}

The contents of shives and fines particles of groundwood pulps are important as they generally indicate wood fiberisation and fibrillation. The model proposed in our previous publication $^{3}$ suggested that the compressiontension power ratio $\left(P_{\mathrm{c}} / P_{\mathrm{t}}\right)$ might be useful in comparing grinding conditions and their effects on shives and fines quantity of groundwood pulps.

The moisture content of wood may play a significant role as well, since it evidently acts as a cushion against intensive strain forces on the fibres, and as a reservoir of heat produced by the mechanical treatments. It seemed evident that at least water-impregnated and air-dried wood should appear very different, because the lumina 


\section{BRUNO LÖNNBERG}

of water-impregnated wood were completely filled by water, while air-dried wood contained only half of the water content that is typical of fibre-wall saturation, i.e. $30 \%$.

Pulp shives thinner than $0.15 \mathrm{~mm}$ indicate the fiberisation efficiency of wood grinding. Figure 1 shows that water-impregnated $(65 \%$ moisture content) and fresh wood (58\%) roughly follow the same trend linear. Drier fresh wood (44\%) would produce less shives than the other fresh wood samples. Wood with water-saturated fibre walls $(28 \%)$ did not seem to differ from a general level of pulp shives, as air-dried wood (15\%) again generated most shives at a high feed rate $(1.3 \mathrm{~mm} / \mathrm{s})$ and low stone speed $(20 \mathrm{~m} / \mathrm{s})$.

However, if the results were analysed for a certain wood moisture content at a time, the trends may be seen as follows. When the feed rate was increased from 1.0 to $1.3 \mathrm{~mm} / \mathrm{s}$, pulp shives increased considerably by about $30 \%$, when grinding water-impregnated wood, fresh wood or air-dried wood at the respective stone speeds of 20,30 and $20-30 \mathrm{~m} / \mathrm{s}$. In the other cases, the increase was $10-20 \%$.

If again considering the wood drying effect on pulp shives, the decrease of the moisture content from 65 to $58 \%$ was not considerable, while decreasing it from 58 to $44 \%$, shives

\section{5 b PGW of Spruce Wood}

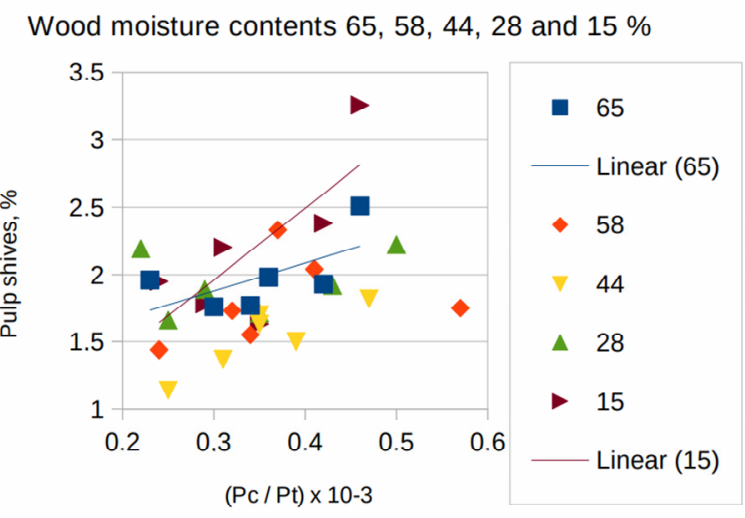

Figure 1: Shives $(>0.15 \mathrm{~mm})$ of groundwood pulp versus compression-tension power ratio in pressure grinding of spruce wood, covering moisture contents from 65 to $15 \%$ diminished particularly at $30 \mathrm{~m} / \mathrm{s}$ stone speed, as again drying from 44 to $28 \%$ increased shives and finally drying from 28 to $15 \%$ increased shives at $20 \mathrm{~m} / \mathrm{s}$ stone speed.

Pulp fines would reflect the effects of strain on the wood and fibre surface, and accordingly elasticity and viscoelasticity of the fibre tissue in connection with the rupture.

Pulp fines described by the compressiontension power ratio followed relatively clear rules, as shown by Figure 2.

Water-impregnated wood $(65 \%)$ and watersaturated fibre walls $(28 \%)$ produced similar amounts of fines, although with significant scatter. Fines produced by dryer fresh wood (44\%) seemed to be close to the trend linear of fresh wood $(58 \%)$, but again with significant deviations. Air-dried wood (15\%) finally acted differently giving a specific trend linear on a level of about $35 \%$, while all other wood samples produced $20-30 \%$ fines.

Since the overall trends were of interest, "false" data had been excluded in this context. After all, the data indicated only the quantities of fines, and accordingly also paper properties must be evaluated to get a truthful picture of the wood moisture effects.

\section{5 b PGW of Spruce Wood}

Wood moisture contents $65,58,44,28$ and $15 \%$

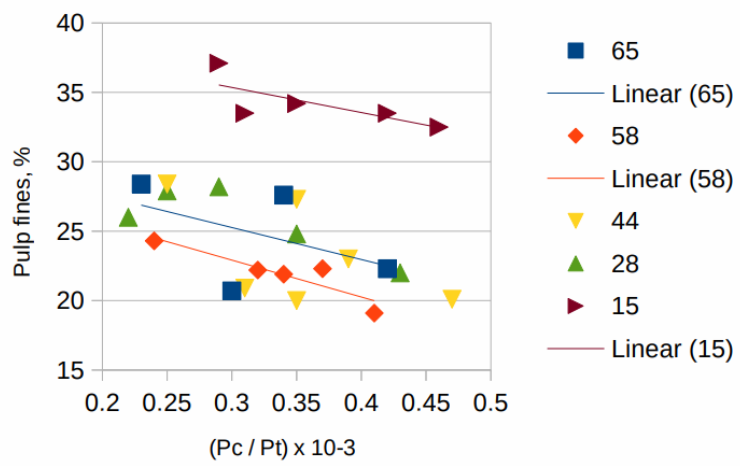

Figure 2: Fines particles (<200 mesh) of groundwood pulp versus compression-tension power ratio in pressure grinding of spruce wood, covering moisture contents from 65 to $15 \%$ 


\section{5 b PGW of Spruce Wood}

Wood moisture contents 65, 58, 44, 28 and $15 \%$

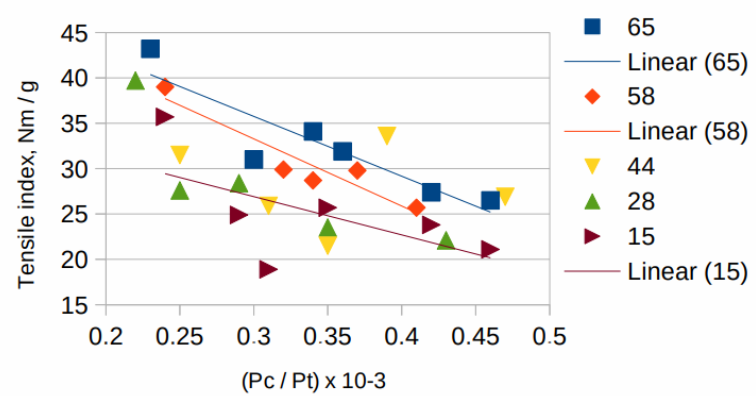

Figure 3: Tensile index of paper made of groundwood pulp versus compression-tension power ratio in pressure grinding of spruce wood, covering moisture contents from 65 to $15 \%$

\section{PAPER TENSILE AND LIGHT SCATTERING}

The tensile and light scattering properties of paper sheets made of the groundwood pulps may explain whether bonding by the fines and the flexibility of fibres contributed to the paper properties. Since it was not possible to separate the effects of fines and fibre flexibility or fibre length, the results provide only rough indications of the true effects.

Water-impregnated wood $(65 \%$ moisture content) and fresh wood (58\%) resulted in the highest tensile properties, as shown in Figure 3. Dryer fresh wood (44\%) and wood with watersaturated fibre walls $(28 \%)$, as well as air-dried wood $(15 \%)$, resulted in low tensile values and with significant deviations. It seemed that wood should be as fresh as possible to guarantee fines and fibres of suitable properties for high tensile strength of the paper. Moreover, a general trend was that lower power ratios resulted in the highest paper strength values, which would be achieved by grinding, for example, fresh wood $(58 \%)$ at low wood feed $(0.7 \mathrm{~mm} / \mathrm{s})$ and high stone speed $(30 \mathrm{~m} / \mathrm{s})$.

The light scattering properties are always important, because they would predict printing properties and opacity of the paper sheet. Generally speaking, Figure 4 shows results that are opposite to those of Figure 3. Thus, fresh wood $(58 \%$ moisture content) produced groundwood pulp that resulted in paper sheets of low light scattering properties, while air-dried
2.5 b PGW of Spruce Wood

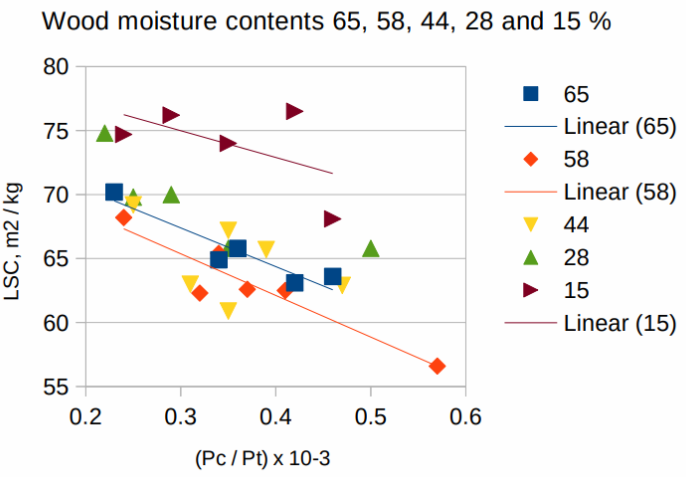

Figure 4: Light scattering coefficient of paper made of groundwood pulp versus compression-tension power ratio in pressure grinding of spruce wood, covering moisture contents from 65 to $15 \%$

wood (15\%) recorded again high values. Generally speaking, grinding of drier wood produced fines particles that resulted in papers of low strength, but high light scattering properties. With fresh wood, the fines particles resulted in reverse properties, i.e. good bonding, but low light scattering properties.

\section{CONCLUSION}

Some general conclusions may be drawn from the results achieved in terms of pulp shives and fines, as well as paper tensile and light scattering properties, expressed as functions of the compression-tension power ratio, as suggested by the novel grinding model developed recently.

The pulp shives did not correlate satisfactorily with the compression-tension power ratio, which might be explained by the fact that even other wood properties, besides the moisture content, have an influence on the shives content. Such wood properties are, for example, heart wood/sap wood and early wood/late wood proportions. It is evident that a minimum of wood moisture content (28\%) corresponding to water saturation of the fibre walls would be enough to ensure at least some viscoelastic behaviour of the fines production due to strain. Air-dried wood (15\%), however, had obviously too dry and too brittle fibre walls, which under strain accordingly produced more fines particles, but with low bonding capacity. The poor bonding properties of the fines accordingly resulted in papers of low tensile, but high light scattering properties. 


\section{BRUNO LÖNNBERG}

\section{REFERENCES}

J.-A. Fagerhed, Planering, byggande och inkörning av en laboratorieslipmaskin (Planning, Construction and Testing of a Laboratory Wood Pulp Grinder), M. Tech. Thesis, Åbo Akademi University, Faculty of Chemical Technology, Åbo, 1987, 57 p.; conducted by Prof. B. Lönnberg, Laboratory of Pulping Technology

2 M. Riissanen, PGW-slipning av fuktkonditionerad ved (Pressure Groundwood Made of Air-Conditioned Wood), M. Tech. Thesis, Åbo Akademi University, Faculty of Chemical Technology, Åbo, 2002, 70 p.; conducted by Prof. B. Lönnberg, Laboratory of Pulping Technology

3 B. Lönnberg, Cellulose Chem. Technol., 54, 49 (2020),

https://doi.org/10.35812/CelluloseChemTechnol.2020 .54 .90

4 B. Lönnberg, in Procs. $9^{\text {th }}$ Fundamental Mechanical Pulp Research Seminar, Trondheim, Norway, May 19-20, 2015, Extended abstract

5 B. Lönnberg, O. Tuovinen and P. Fardim, in Procs. $10^{\text {th }}$ Fundamental Mechanical Pulp Research Seminar, Jyväskylä, Finland, June 13-14, 2017, Extended abstract, https://afrc.fi/fmprs2017/ 